\title{
An investigation of the most Flow Inducing Genres
}

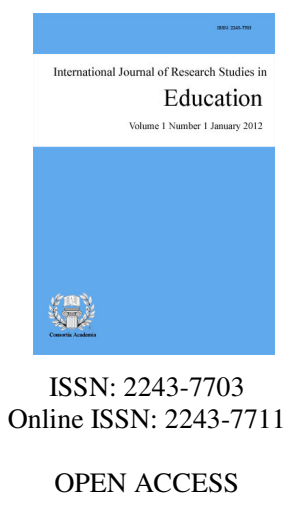

\section{Abstract}

The present study aims at examining the extent to which three discourse genres of descriptive, expository, and narrative would be flow inducing. In other words, it attempts to testify the role of the text in promoting optimal experience on the one hand, and to identify which discourse genre would be the most flow inducing, on the other hand. To this end, a community sample of 60 participants comprising of 16 males and 44 females from various English language institutes in Mashhad, volunteered to take part in the study by reading three texts of TOEFL containing the expository, narrative, and descriptive genres. After each reading the respondents were asked to reflect on their flow experience through filling in the Flow Perception Questionnaire (Egbert, 2003). The researchers investigated flow differences across genres by employing repeated measures ANOVA. The results revealed that flow occurred during the reading of descriptive, narrative, and expository genres; however, there were significant differences in terms of the flow scores engendered by the variations across these genres. The results of the data analysis reported the descriptive genre as the most flow inducing discourse genre.

Keywords: discourse genres; flow; reading; optimal experience; ANOVA 


\section{An investigation of the most Flow Inducing Genres}

\section{Introduction}

Why do people get involved in time-consuming, difficult, and often dangerous activities for which they receive no extrinsic reward? This question started to be asked since the last quarter of the previous century, and originally led Csikszentmihalyi into a program of research that required numerous interviews with hundreds of rock climbers, chess players, athletes, and artists. These interviews revealed that in all the various groups, the respondents reported a very similar subjective experience to the point that they were willing to experience it again even at a great cost. This was eventually called flow experience, because while describing how it felt when the activity was going well, several of the respondents used the metaphor of a "current" which carried them effortlessly (Csikszentmihalyi, 1975; Nakamura \& Csikszentmihalyi, 2002, as cited in Csikszentmihalyi, Abuhamdeh, \& Nakumara, 2005).

Flow is a subjective state of skill-challenge balance which is also characterized by a person's interest, control, and intense focus (Csikszentmihalyi, 1975). The paper at hand deals with the flow experience while reading different modes of writing. Traditionally, non-creative modes of writing have been classified into four types:

$>$ Descriptive writing provides a verbal picture or account of a person, place or thing.

$>\quad$ Narrative writing reports an event or tells the story of something that happened.

$>$ Expository writing provides information about and explains a particular subject. Patterns of development within expository writing include giving examples, describing a process of doing or making something, analyzing causes and effects, comparing and/or contrasting, defining a term or concept, and dividing something into parts or classifying it into categories.

$>\quad$ Argumentative writing attempts to support a controversial point or defend a position on which there is a difference of opinion.

Since reading, just as any other activity may engender flow (McQuillan \& Conde, 1996; Massimini, Csikszentmihalyi, \& DelleFave, 1998; Egbert, 2003) it seems reasonable to investigate which modes of writing would be more flow-generating than the others. In sum, this paper takes exclusively descriptive, narrative, and expository genres into account. Specifically, the present study aims at answering the following questions:

$>$ RQ1. Can the expository, narrative, and descriptive genres be flow inducing?

$>\quad$ RQ2. Are there any significant differences across the descriptive, narrative, and expository genres in terms of inducing optimal experience?

\section{Literature Review}

Flow experiences are periods of deep, intense involvement in activities that challenge but do not overwhelm one's skills (Mirlohi, Egbert, \& Ghonsooly, 2011). It is a state in which people feel regulated by their actions. During flow a person experiences a deep sense of pleasure that is long revered and that becomes a landmark in memory for what life should be like (Csikszentmihalyi, 1990). As further characterized by Csikszentmihalyi:

"Flow is the key to intrinsic motivation; it is the state in which people are so involved in an activity

that they lose track of time and nothing else seems to matter; the experience itself is so enjoyable

that people will even go to great lengths to do it just for the sheer sake of doing it" (p. 4). 
A growing body of research has been conducted on the concept of flow since 1980s by probing deep into such activities as dancing, child-raising, surgery, reading, surfing the internet, playing football, doing art and math, rock climbing, and communicating via computers, music, education, sports has expanded flow theory into a robust and empirically established theory (Asakawa, 2004; Csikszentmihalyi \& Csikszentmihalyi, 1988; Inghilleri, 1999; McQuillan \& Conde, 1996; Massimini \& DelleFave, 2000; Webster, Trevino, \& Ryan, 1993; Custodero, 2002; Gimeno \& Gonzalez-CutreColl, 2008). Flow researchers have disclosed that the quality of experience during flow is characterized by intense focus, cognitive efficiency, a perceived skills-challenge balance, immediate feedback, merging of action and awareness, a sense of control, enjoyment, the opinion that time passes quickly, clearly defined task objectives and a lack of self-consciousness (Egbert, 2003; Wanner, Ladouceur, Auclair, \& Vitaro, 2006). To persist in experiencing flow, one must enhance the complexity of the activities by promoting new skills corresponding to the new challenges (Carl, 1994).

Since flow is a form of motivation, it is an intrinsically salient human resource (Csikszentmihalyi, 1975). Kubey and Csikszentmihalyi (1990) believed that flow may also be observed as a stimulus for personal development and higher learning as one needs to catch up with the challenge and to keep experiencing it. To gain the flow state, one must be progressively engaged with higher skill levels or he might enhance the level of challenge to cater for the skill levels. In other words, two major criteria must be met in order to acquire the flow state (Csikszentmihalyi, 1988, 1990, 1997). Firstly, the perceived challenge posed by an activity must be in concert with the individual's activities or skills to relish the challenges and secondly, such perceived challenges and perceived abilities or skills must be relatively at a high level (Massimini \& Carli, 1988; Massimini, Csikszentmihalyi, \& Carli, 1987). Henceforth, optimal experience would drive people into stretching themselves in an attempt for taking on more and more challenges and upgrading their skills and abilities (Csikszentmihalyi, 1988).

The experience is actuated by a good fit between the person's skills in an activity and the challenges afforded by the environment (Rathnude, 2003). If the level of challenge is too high and the available skill is too low, in return, anxiety occurs, whereas low challenge and high skills induce boredom. Based on Csikszentmihalyi (1990), the right balance engenders an optimal experience which is highly marked by a sense that all skills are adequate to cope with the challenges at hand in a good directed, rule bound action system that provides clear clues as how one is performing.

When experiencing flow, the individual would be engrossed in the activity in as much as they lose track of time due to their loss of self-awareness or self-consciousness; hence, no distraction might affect their concentration and finally there would be a sense of oneness with the activity (Csikszentmihalyi, 1988). Thus, attention as a flow dimension is the medium that makes an event occur in consciousness and can be taken as a psychic energy (Csikszentmihalyi, 1988). Taking James' (1890) understanding into account, it's of prime importance for each person to develop undivided attention, or the ability to get engaged with the task in a way that is enjoyable and productive, at the same time.

Awareness is regarded as another flow dimension which entails identifying the stimulus, categorizing it with regards to the previous information, and organizing it by remembering or forgetting it (Csikszentmihalyi, 1988). "When the mind and body transact synergistically in flow, this psychological state of being would be gained which enables evolution of self by internal awareness" (Mendelsen, 2007, p. 33). Whalen (1997) believed that contexts such as school are more flow generating if they supply learners with sufficient opportunities for self-regulating activities and self-expression. Therefore, autonomy-supporting situations are more conducive to flow generating conditions regarding the environments in which learners have no choice (Mirlohi, Egbert, \& Ghonsooly, 2011).

Nonetheless, interest plays a leading role in engaging learners with a task for its own sake and yields a foundation for future learning and ongoing motivation (Deci \& Ryan, 1987). In fact, flow has revealed to promote learning and development since experiences of deep and total concentration are intrinsically rewarding 
and they mobilize the students for the repetition of the activity at higher levels of challenge (Csikszentmihalyi, Rathnude, \& Walden, 1997). Moreover, within the context of language learning, reading is one of the fundamental complementary skills during which the reader integrates the previously acquired knowledge and skills to comprehend a message from a writer (Haji Maibodi, 2008). Since the richer the schema is for a given topic, the better the reader will comprehend that topic; some students' alleged reading difficulties may stem from their insufficient background knowledge (Carrell, 1988).

Several studies reveal that reading is a complex process through which the recreation of the writers' intended meaning emerges when the reader combines the textual information with his or her background knowledge (Haji Maibodi, 2008). According to Chastain (1988), reading is sometimes erroneously deemed as a passive skill since the reader doesn't produce messages in the same sense as a speaker or writer does; nevertheless, reading requires mental processing for communication to take place; however, "reading is considered as the most widely reported flow inducing activity in the optimal experience literature" (McQuillan \& Conde, 1996, p. 114).

According to the Interactive Model proposed by Eskey (1988), there is an indispensable interaction between the reader and the text on the one hand, and between lower and higher levels of reading process, on the other hand. Lower level skills are known as decoding skills for extracting explicit information, whereas higher level skills entail more cognitive effort to discern the implicit information. Sato (1988) has done a number of flow studies in which nearly all the participants noted reading as an optimal experience generating activity. Besides, more than twenty percent of the broad cultural groups surveyed by Massimini, Csikszentmihalyi, and DelleFave (1998) reported reading as a flow inducing activity they engaged in, since they found themselves involved and immediately immersed in the reading in as much as they felt completely belonged to the context described and could identify themselves with the characters of the book.

Concerning the fact that one of the prominent complementary skills in language learning is reading (Haji Maibodi, 2008) it would be worthwhile to examine the role of the text genre in promoting optimal experience.

\section{Methodology}

\subsection{Participants}

A community sample of 60 English learners comprising of 44 females and 16 males voluntarily took part in this study with no expectation of rewards. They were advanced EFL learners who were studying at language institutes in Mashhad. Their mean age was 25.65 ranging from 18 to 44 years. Indeed, they had no prior information about various modes of writing.

\subsection{Procedure}

The study initiated at the beginning of the winter semester during the participants' regular class hours after seeking permission from the instructors. It was aimed to assess the flow achievement degree while reading three discourse genres of expository, narrative, and descriptive texts of TOEFL. Therefore, every attempt was made to have the students under the same standard TOEFL test conditions. The students were made quite assured that the results would remain confidential and their instructors were not allowed to have access to their TOEFL' s reading scores. After receiving clear instructions, they were asked to go through each discourse genre and answer the related questions during the standard time and immediately afterwards, mark their degree of agreement or disagreement with each of the items on seven-point Likert-type rating scale of Flow Perception Questionnaire. Subsequently, they were asked to respond to eight open-ended questions on the Flow Dimension Open- Ended Form. It was strongly stressed that the questionnaires had to be filled in right after the reading of each text and that they were related to the text just being read. The collected data were put into Statistical package for Social Sciences (SPSS) to be analyzed. The mean differences in the descriptive statistics and the multivariate test were 
analyzed to answer the research questions.

\subsection{Instruments}

There are numerous ways to measure optimal experience (Nakamura \& Csikszentmihalyi, 2009, as cited in DelleFave, Massimini, \& Bassi, 2011) the majority of which have been concentrated on the individuals' self-report of their experiential state and of their surrounding environment (DelleFave, Massimini, \& Bassi, 2011, p. 59). Harré and Secord (1972) asserted that these are regarded as true descriptions depending on human abilities to perceive and describe oneself. Thus, for further investigation of the research questions, both Flow Perception Questionnaire and Flow Open-Ended Form have been employed to provide convincing evidence to capture the flow experience.

Tasks and Texts - Three discourse genres were selected: expository, narrative, and descriptive The three various modes of writing with the average words of 250 were taken from "Longman Complete Course for the TOEFL Test" (Phillips, 2001). The readability of the texts was checked in two ways to ensure having the same level of challenge. In the first place, Flesch-Kincaid Grade Level score was utilized to examine the built-in structure of the texts which reported the computed readability score of 12.04 for the expository, 12.10 for the narrative, and 12.21 for the descriptive genre; henceforth, the three selected texts proved to be nearly at the same level of difficulty. Moreover, three university professors judged the overall level of difficulty of the texts as nearly similar regarding their readability.

In addition, the Flow Perception Questionnaire (in English) (see Appendix A) (Cronbach's $\alpha=.82$ ) taken directly from Egbert (2003) was used for the purpose of assessing the flow degree. This questionnaire contained 14 items in the seven-point Likert-type rating scale format from 7 (strongly agree) to 1 (strongly disagree). Questions 4, 10, and 12 were scored reversely.

The flow dimension open-ended form was utilized in an attempt to investigate whether the participants who had gained high scores on the survey for specific tasks had really undergone the flow experience during reading or not. It consisted of eight open-ended questions (see Appendix B) dealing with the flow dimension, and examining the participant's reactions as they were experiencing flow while doing each task. Moreover, the participants were provided with the chance of responding to these questions either in Persian or English. Indeed, both of the employed questionnaires were pilot tested with a group of 20 EFL language learners beforehand for the sake of intelligibility.

\section{Results}

A one-way repeated measures ANOVA was conducted to compare scores on the expository, narrative, and descriptive genres. The means and standard deviations are presented in Table 1. As it can be noted, the descriptive text had the highest mean of (66.00) compared to the narrative text (60.73) and the expository text (61.61).

\section{Table 1}

Descriptive Statistics of All Flow Scores across Each Task and All Tasks

\begin{tabular}{llll}
\hline Genres & Mean & SD & N \\
\hline Expository & 61.6156 & 11.34427 & 60 \\
Narrative & 60.7313 & 10.61020 & 60 \\
Descriptive & 66.0034 & 11.53159 & 60 \\
\hline
\end{tabular}

According to Egbert (2003), previous research designates a flow experience as being above average on skills and challenge. That is, the participants who scored 60 or above on any survey (equivalent to "agree" on all questions) are designated as having experienced flow. Factually, as the table above indicates, it can be concluded 
Ghonsooly, B. \& Hamedi, S. M.

that all the three genres have engendered flow. The findings of this research is in line with Massimini, Csikszentmihalyi, and DelleFave (1998), and Egbert (2003) who have considered reading as the most common optimal experiencing activity. It also asserts Mirlohi, Egbert, and Ghonsooly's (2011) findings in that the descriptive text had the highest and the narrative text had the lowest mean, respectively. Probing the significant differences across discourse genres in terms of the extent to which these texts are flow inducing, one-way repeated measures ANOVA findings are presented in Table 2.

Table 2

Repeated Measures ANOVA Analysis of Flow Score Means

\begin{tabular}{lllrlrrr}
\hline & \multicolumn{1}{c}{ Effect } & Value & F & Hypothesis df & Error df & $\begin{array}{c}\text { Sig. } \\
\text { Partial Eta } \\
\text { Squared }\end{array}$ \\
\hline Genres & Pillai's Trace & .118 & $3.889 \mathrm{a}$ & 2.000 & 58.000 & .026 & .118 \\
& Wilks' Lambda & .882 & $3.889 \mathrm{a}$ & 2.000 & 58.000 & .026 & .118 \\
& Hotelling's Trace & .134 & $3.889 \mathrm{a}$ & 2.000 & 58.000 & .026 & .118 \\
& Roy's Largest Root & .134 & $3.889 \mathrm{a}$ & 2.000 & 58.000 & .026 & .118 \\
\hline
\end{tabular}

As a result, there was a significant effect for genre Wilks' Lambda $=.88, \mathrm{~F}(2,58)=3.88, p<.05$, multivariate partial eta squared $=.11$. As follows from the table, the calculated effect size would be .11 which shows according to Cohen (1988) a moderate effect. That is, around $11 \%$ of the variance in dependent variable (flow score) can be explained by the variance in the independent variable (the three discourse genres). To investigate where these statistically significant differences in the mean scores of the three discourse genres lie, post-hoc analyses have been utilized (Table 3).

Table 3

Pairwise Comparisons

\begin{tabular}{|c|c|c|c|c|c|c|}
\hline \multirow[b]{2}{*}{ (I) Genres } & \multirow[b]{2}{*}{ (J) Genres } & \multirow{2}{*}{$\begin{array}{l}\text { Mean } \\
\text { Difference(I-J) }\end{array}$} & \multirow[b]{2}{*}{ Std. Error } & \multirow[b]{2}{*}{ Sig. ${ }^{a}$} & \multicolumn{2}{|c|}{$\begin{array}{l}95 \% \quad \text { Confidence } \\
\text { Difference }\end{array}$} \\
\hline & & & & & Lower Bound & Upper Bound \\
\hline \multirow[t]{2}{*}{1} & 2 & .884 & 1.908 & 1.000 & -3.817 & 5.586 \\
\hline & 3 & -4.388 & 1.990 & .094 & -9.292 & .517 \\
\hline \multirow[t]{2}{*}{2} & 1 & -.884 & 1.908 & 1.000 & -5.586 & 3.817 \\
\hline & 3 & $-5.272^{*}$ & 1.982 & .030 & -10.157 & -.387 \\
\hline \multirow[t]{2}{*}{3} & 1 & 4.388 & 1.990 & .094 & -.517 & 9.292 \\
\hline & 2 & $5.272^{*}$ & 1.982 & .030 & .387 & 10.157 \\
\hline
\end{tabular}

Depending on Table 3, there is a statistically significant difference between the means scores of pairs 2 (narrative) and 3 (descriptive) genres. Based on Table 1, the means of the flow scores of narrative (60.73) and expository (61.61) texts are lower than that of descriptive text (66.00). Moreover, according to the post-hoc analyses, the difference lies within the mean differences of the descriptive and narrative genres. Therefore, the descriptive genre is the major cause of the incidence of flow in reading. The result can also be corroborated by the findings of Mirlohi, Egbert, and Ghonsooly's (2011) research in the field of translation.

\section{Discussion}

How students feel while doing diverse classroom activities can exert a great influence on the language learners' learning or performance. One of these effectual feelings is the feeling of flow, by which the learners are absorbed in an activity to the point that they lose track of time and place, and they enjoy doing the activity for its own sake; thus, there is a good possibility that students will do the activity again and again willingly, so their learning and as a result their performance will improve, consequently. Indeed, depending on the informants' responses to the Flow Open-Ended Form, a number of major factors leading to the experience of flow have been demonstrated which are thoroughly characterized below:

The participants reported (a) interest as the most prominent factor in captivating their attention towards 
attending to the text, (b) extremely unfamiliar and novel topics which could arouse their curiosity, and (c) the activation of their prior knowledge due to their familiarity with the reading content. Psychologically speaking, the equilibrium must be made in between their skill level, text challenge, personal interest, and their prior knowledge, accordingly. Moreover, shorter texts with fewer technical terms were reported to enable the learners feel more in control of the task. Besides, having relatively numerous proper nouns and numerical expressions was mentioned to drastically spoil their concentration and destroy their immersion. Ultimately, the existence of visual cues such as pictures was stated as another contributory factor in creating the flow state.

As a result, the teachers can enhance the students' level of interest and engagement in reading if only due attention is paid to the aforementioned reader-reported remarks while selecting the curricular reading texts for the class. According to the mean scores of the discourse genres, all the three genres were demonstrated to be flow-inducing, among which, the descriptive mode proved to be the most flow generating one. The underlying justification could be the presence of relevant visual cues in the text, learners' higher interest and prior knowledge due to having watched documentaries, or having read stories related to the topic. Lastly, the shorter length of the text could play a key role in triggering the flow state.

The dynamism created by challenging, intrinsically rewarding activity and requisite skill suggests that the identification of flow in learning environments should inform pedagogical practices (Custodero, 2002). People are most highly encouraged when they have opportunities to influence the quality of their engagement and when they perceive a sense of autonomy (Deci, 1995). A growing body of research has indicated that the attainment of self-knowledge and self-growth from the flow experience provides teachers with a rationale for the reanalysis of their strategies and prompts appropriate curricular choices. As a result, the findings provide an insight into the utmost significance of the meticulous selection of the most flow inducing texts to provide more opportunities for the learners' active participation and to design instructional course books with highly enjoyable and motivating activities to appreciate the indispensable relationship between enjoyment and learning and to ask for the students willing cooperation towards extending their own understanding to become better critical thinkers in future. To this end, high value must be placed on the students' experience which calls for the school policy's support of this framework by adopting a system view that honors the learners' collaboration and by providing sufficient amenities which enables teachers and learners for higher investigation of their ideas.

Concerning the limitations of the study at hand regarding its sample size, the operational predicaments of measuring a highly subjective experience such as flow, the results of the study should be inevitably interpreted cautiously; however, it still has major implications for material developers, test designers, language instructors, and language learners.

\section{Conclusion}

The present study sought to examine the concept of flow in reading on the one hand, and to testify the differences across various modes of writing as a predictor to ensure the flow generating state, on the other hand. The findings of the study are in consistent with Massimini, Csikzentmihalyi, and DellFave (1998) who considered reading as a flow generating activity. Furthermore, the present study suggests that there are significant differences across various genres of texts in generating optimal experience. Therefore, the employed mode of writing can be taken as a leading predictor for the flow experience level. Based on the descriptive statistics, the descriptive genre has the highest impact on flow inducing situation whereas the expository and narrative genres come as the second and third best; however, post-hoc analyses exhibited statistically significant differences merely between the narrative and descriptive genres.

\section{References:}

Asakawa, K. (2004). Flow experience and autotelic personality in Japanese college students: How do they experience challenges in daily life? Journal of Happiness Studies, 5, 123-154. 
Ghonsooly, B. \& Hamedi, S. M.

http://dx.doi.org/10.1023/B:JOHS.0000035915.97836.89

Carrell, P. (1988). Some causes of text boundedness and schema interference in ESL reading. In P. L. Carrell, J. Devine, \& D. E. Eskey (Eds.), Interactive approaches to second language reading (pp. 101-113). New York: Cambridge University Press. http://dx.doi.org/10.1017/CBO9781139524513.012

Csikszentmihalyi, M. (1975). Beyond boredom and anxiety. San Francisco: Jossey Bass.

Csikszentmihalyi, M. (1988). The flow experience and its significance for human psychology. In M.

Csikszentmihalyi \& I.S. Csikszentmihalyi (Eds.), Optimal experience: Psychological studies of flow in consciousness (pp. 15-35). New York: Cambridge University Press. http://dx.doi.org/10.1017/CBO9780511621956.002

Csikszentmihalyi, M. (1990). Flow: The psychology of optimal experience. New York: Harper and Row.

Csikszentmihalyi, M. (1996). Creativity, Flow and the psychology of discovery and invention. New York: Harper Perennial.

Csikszentmihalyi, M. (1997). Finding flow: The psychology of engagement with everyday life. New York: Harper Collins.

Csikszentmihalyi, M., \& Csikszentmihalyi, I. S. (1988). Optimal experience: Psychological studies of flow in consciousness. New York: Cambridge University Press. http://dx.doi.org/10.1017/CBO9780511621956

Csikszentmihalyi, M., Abuhamdeh, S., \& Nakamura, J. (2005). Flow. In A. Elliot (Ed.), Handbook of competence and motivation (pp. 598-698). New York: The Guilford Press.

Csikszentmihalyi, M., Rathnude, K., \& Whalen, S. (1997). Talented teenagers: The root of success and failure. New York: Cambridge.

Custodero, L. A. (2002). Seeking challenge, finding skill: Flow experience and music education. Arts Education Policy Review, 103, 33-39. http://dx.doi.org/10.1080/10632910209600288

Deci, E. L. (1995). Why we do what we do. New York: Penguin books.

Deci, E. L., \& Ryan, R. M. (1987).The support of autonomy and the control of behavior. Journal of Personality and Social Psychology, 53, 1024-1037. http://dx.doi.org/10.1037/0022-3514.53.6.1024

DelleFave, A., Massimini, F., \& Bassi, M. (2011). Psychological selection and optimal experience across cultures. New York: Springer. http://dx.doi.org/10.1007/978-90-481-9876-4

Egbert, J. (2003). A study of flow theory in the foreign language classroom. The Modern Language Journal, 87, 499-518. http://dx.doi.org/10.1111/1540-4781.00204

Eskey, D. E. (1988). Holding in the bottom: An interactive approach to the language problems of second language readers. In P. L. Carrell, J. Devine, \& D. E. Eskey (Eds.), Interactive approaches to second language reading (pp.168-182). Cambridge: Cambridge University Press. http://dx.doi.org/10.1017/CBO9781139524513.011

Haji Maibodi, A. (2008). Learning English through short stories. Iranian Journal of Language Studies, 2(1), 41-72.

Harré, R. \& Secord, P. F. (1972). The explanation of social behavior. London: Basic Blackwell.

Inghilleri, P. (1999). From subjective experience to cultural change. Cambridge: Cambridge University Press. http://dx.doi.org/10.1017/CBO9780511571343

James, W. (1890). The principles of Psychology. New York: Henry Holt. http://dx.doi.org/10.1037/11059-000

Kubey, R., \& Csikszentmihalyi, M. (1990). Television and the quality of life: How viewing shapes everyday experience. Hillsdale, NJ: Lawrence Erlbaum.

Massimini, F., \& Carli, M. (1998). The systematic assessment of flow in daily experience. In M.

Csikszentmihalyi \& I. S. Csikszentmihalyi (Eds.), Optimal experience: Psychological studies of flow in consciousness (pp. 288-306). New York: Cambridge University Press.

Massimini, F., \& DelleFave, A. (2000). Individual development in a bio-cultural perspective. American Psychologist, 55, 24-33. http://dx.doi.org/10.1037/0003-066X.55.1.24

Massimini, F., Csikszentmihalyi, M. \& DelleFave, A. (1988). Flow and bicultural evolution, in M.

Csikszentmihalyi \& I. S. Csikszentmihalyi (Eds.), Optimal experience: Psychological studies of flow in consciousness (pp. 342-363). New York: Cambridge University Press.

http://dx.doi.org/10.1017/CBO9780511621956.004 
An investigation of the most Flow Inducing Genres

Massimini, F., Csikszentmihalyi, M., \& Carli, M. (1987). The monitoring of optimal experience: A tool for psychiatric rehabilitation. Journal of nervous and mental disease, 175(9), 545-549. http://dx.doi.org/10.1097/00005053-198709000-00006

McQuillan, J., \& Conde, G. (1998). The conditions of flow in reading: Two studies of optimal experience. Reading Psychology: An International Quarterly, 17, 109-135. http://dx.doi.org/10.1080/0270271960170201

Mendelsen, N. (2007). The functional mediation of flow between achievement, anxiety, academic procrastination and academic performance. Unpublished $\mathrm{PhD}$ thesis, the University of Fordham.

Mirlohi, M., Egbert, J., \& Ghonsooly, B. (2011). Flow in translation: Exploring optimal experience for translator trainees. Target, 23(2), 250-271. http://dx.doi.org/10.1075/target.23.2.06mir

Nakamura, J., \& Csikszentmihalyi, M. (2002). The concept of flow. In C. R. Snyder \& S. J. Lopez (Eds.), Handbook of positive psychology (pp. 89-105). New York: Oxford University Press.

Phillips, D. (2001). Longman complete course for the TOFEL test. New York: Longman.

Rathnude, K. (1988). Optimal experience and family context. In M. Csikszentmihalyi \& I. S. Csikszentmihalyi (Eds.), Optimal experience: Psychological studies of flow in consciousness (pp. 342-363). New York: Cambridge University Press.

Rathnude, K. (2003). A comparison of Montessori and traditional middle schools: Motivation, quality of experience and social context. The NAMTA Journal, 28(3), 13-41. http://dx.doi.org/10.1017/CBO9780511621956.021

Sato, I. (1988). Bosozoku: Flow in Japanese motorcycle gangs. In M. Csikszentmihalyi \& I. Csikszentmihalyi (Eds.), Optimal experience: Psychological studies of flow in consciousness (pp. 92-117). Cambridge: Cambridge University Press. http://dx.doi.org/10.1017/CBO9780511621956.006

Wanner, B., Ladouceur, R., Auclair, A. V., \& Vitaro, F. (2006). Flow and dissociation: Examination of mean levels, cross-links, and links to emotional well-being across sports and recreational and pathological gambling. Journal of Gambling Studies, 22(3), 289-304. http://dx.doi.org/10.1007/s10899-006-9017-5

Webster, J., Trevino, L., \& Ryan, L. (1993).The dimensionality and correlates of flow in human computer interactions. Computers in Human Behavior, 9, 411-426. http://dx.doi.org/10.1016/0747-5632(93)90032-N

Whalen, S. (1997). Assessing flow experience in highly adolescent learners. Paper presented at the Annual Meeting of the American Educational Research Association, Chicago, IL. 


\section{Appendix A: Flow Perceptions Questionnaire}

1. This task excited my curiosity.

2. This task was interesting in itself.

3. I felt that I had no control over what was happening during this task.

4. When doing this task I was aware of distractions.

5. This task made me curious.

6. This task was fun for me.

7. I would do this task again.

8. This task allowed me to control what I was doing.

9. When doing this task, I was totally absorbed in what I was doing.

10. This task bored me.

11. During this task, I could make decisions about what to study, how to study it, and/or with whom to study.

12. When doing this task I thought about other things.

13. This task aroused my imagination.

14. I would do this task even if it were not required.

\section{Appendix B: Flow-Dimension-Open-Ended Form}

1. What did you find challenging or too hard in this task?

2. What did you find that was boring or too easy?

3. What made this task interesting to you?

4. What made this task not interesting to you?

5. What helped you to focus on this task?

6. What made you lose focus during this task?

7. What parts of the task could you control?

8. What parts of the tasks could you not control? 